Article

\title{
Simulation of the Reactivation of Partially Inactivated Biocatalysts in Sequential Batch Reactors
}

\author{
Nadia Guajardo ${ }^{1, *}$ (D) Fernando A. Crespo ${ }^{2, *}$ and Rodrigo A. Schrebler ${ }^{3}$ \\ 1 Programa Institucional de Fomento a la Investigación, Desarrollo e Innovación, \\ Universidad Tecnológica Metropolitana, Ignacio Valdivieso 2409, San Joaquín, Santiago 8940000, Chile \\ 2 DAiTA LAB, Facultad de Estudios Interdisciplinarios, Universidad Mayor, Badajoz 130, Las Condes, \\ Santiago 7550000, Chile \\ 3 IONCHEM Spa., El Tordillo 154, Villa Alemana 6500000, Chile; rodrigoschrebler@hotmail.com \\ * Correspondence: nguajardo@utem.cl (N.G.); facrespo@gmail.com or fernando.crespo@umayor.cl (F.A.C.); \\ Tel.: +56-227-877-910 (N.G.); +56-983-600-401 (F.A.C.)
}

Received: 28 September 2020; Accepted: 4 November 2020; Published: 8 November 2020

\begin{abstract}
The enzymatic reactivation process enables the recovery of catalytic activity for inactive biocatalysts. However, its effect on the specific productivity of the processes has not been studied. The main objective of this work was to evaluate the specific productivity of the processes with and without reactivation using the program Spyder Python (3.7). Using fixed values for all of the parameters, the global specific productivity was $8 \mathrm{mM} / \mathrm{h} \cdot \mathrm{g}_{\text {biocat }}$ for the process without reactivation, and $4 \mathrm{mM} / \mathrm{h} \cdot \mathrm{g}_{\text {biocat }}$ for the process with reactivation. Random numbers were generated to use as different values for parameters, and the results yielded a global specific productivity of $3.79 \mathrm{mM} / \mathrm{h} \cdot \mathrm{g}_{\text {biocat }}$ for the process with reactivation and $3.68 \mathrm{mM} / \mathrm{h} \cdot \mathrm{g}_{\text {biocat }}$ for the process without reactivation. ANOVA tests showed that there were significant differences between the specific global productivities of the two processes. Reactivation has great potential for use when the biocatalyst is of high cost.
\end{abstract}

Keywords: enzyme reactivation; enzyme inactivation; bioreactors; sequential batch bioreactor simulation

\section{Introduction}

Enzymes are biological catalysts that offer advantages over conventional chemical catalysts due to their high specificity, high activity under moderate reaction conditions, high rotation number and biodegradability [1]. Enzymes were first used in 1914 and their large-scale microbial production began in the 1960s. The commercialization of enzymes at an industrial scale is growing, thanks to new technologies in the field of fermentation and molecular biology (protein engineering) [2]. The global enzyme market is projected to grow from USD 5.01 billion in 2016 to USD 6.32 billion in 2021 [1,3].

Due to their biological nature, the enzymes used are labile and their activity and stability is affected in the presence of aggressive conditions of $\mathrm{pH}$, temperature [4] and organic solvents [5]. The phenomenon of enzymatic inactivation is a consequence of changes in the conformation of the protein structure, which alters the protein from its original state to different, less functional conformational states [6-9]. These changes are produced by the interaction of the amino acids of the protein with the surrounding environment $[6,7]$. For example, in aqueous media, polar amino acids at the surface are exposed to interactions with the solvent, while the non-polar amino acids are located internally, interacting more with each other. Due to this form of folding, it is proposed that one of the main factors that determines protein stability is the hydrophobic interaction of the internal three-dimensional structure [10], which counteracts the surface forces that tend to alter the 
structure. Thus, extending original functional structure over time is one of the main challenges of enzyme technology.

The ability of hydrolytic enzymes to catalyze synthesis reactions in non-aqueous media [11-13] has generated interest in the research and development of enzymatic processes in non-conventional media, in which it has been observed that the inactivation phenomenon is severe, even for immobilized enzymes [14]. Solvent inactivation is caused by the exposure of the internal non-polar amino acid residues of the protein, which results in unfolding and loss of the protein structure [15].

Different strategies have been developed to improve the stability of enzymes, for example, immobilization onto supports by covalent attachment [15-17]. This method stiffens the protein structure and makes it less sensitive to inactivating agents such as temperature and $\mathrm{pH}$, which results in greater enzymatic stability [18]. Such advances have increased the interest in applying enzymes in industrial processes. Although immobilization offers an alternative for increasing the stability of enzymes, this is often not sufficient and, in the presence of non-conventional media, biocatalysts suffer from inactivation.

In order to recover enzymatic activity, an alternative is the reactivation method. Reactivation is based on the fact that the conformational changes which cause inactivation of the enzyme are reversible, and the activity of the enzyme can be recovered [13,19]. Biocatalysts are partially inactivated when incubated in aqueous media using organic solvents as co-solvents, however the activity of the biocatalyst can be recovered by removing it from the denaturing media and incubating it again in a buffered media. The recovery of enzyme activity after incubation in aqueous media depends on the concentration of the co-solvent. In Romero et al. [20], the activity of the partially inactivated biocatalyst was fully recovered after incubation in phosphate buffer using $70 \%$ of cosolvent. However, when the enzyme is completely inactivated, its activity can only be partially recovered [8]. In that case, it is necessary to use a chaotropic agent (e.g., urea at $10 \mathrm{mM}$ ) to reduce the number of S-S bonds of the amino acids in protein, unfolding the polypeptide chains (forming $\mathrm{SH}$ groups), and oxidizing it with, for example, glutathione; this almost completely recovers the activity of the biocatalyst. Rueda et al. [21] recovered $95 \%$ activity of lipase B from Candida antarctica (CALB) immobilized in glyoxyl agarose after being incubated in dimethylformamide (DMF) $90 \%(v / v)$. It was reactivated using guanidine $9 \mathrm{M}$ as the chaotropic agent. Thermomyces lanuginosus lipase (TLL) was immobilized in glyoxyl agarose and $80 \%$ of activity was recovered after it was incubated in $80 \%(v / v)$ 1,4-dioxane and reactivated with guanidine $9 \mathrm{M}$.

In this way, the chaotropic agents that are denaturating agents fully deploy the enzymatic tertiary structure, and later, in an aqueous incubation stage, restore the native and functional structure. This unfolding-folding strategy allows the elimination of strong or covalent interactions established during the inactivation process, which prevents the restoration of the original native structure $[19,22]$. This strategy demonstrates the importance of multi-point immobilization technology, since it is the maintenance of this pattern of covalent junctions that allows the unfolded enzyme to fold back correctly and adopt the original functional configuration [23-26]. One way to assess the stability of a biocatalyst is to use the sequential batch reactor strategy, in which the reactivated or non-reactivated biocatalyst is recovered and reused in subsequent reaction cycles $[27,28]$.

According to the literature, the enzyme reactivation strategy could increase the useful life of a biocatalyst in reactions in non-conventional media, ultimately reducing production costs. However, its implementation must be evaluated because reactivation takes time that can affect the productivity of a process. For this reason, the main objective of this work was to evaluate the specific productivity of the reactivation strategy using simulations in successive batch reactors.

\section{Process Description and Mathematical Formulation}

\subsection{Mathematical Formulation}

The simulation was performed for a stirred batch reactor operating in sequential batch mode (Figure 1) under the following considerations: 
- Michaelis-Menten enzymatic kinetics

- First-order catalytic inactivation kinetics

- Fixed temperature at $25^{\circ} \mathrm{C}$

- $90 \%$ conversion in each production lot

- $25 \%$ residual activity as the limit of each operation

- Equimolar reaction with 1:1 substrate:product ratio

- No dead times between each production batch

- Including a reactivation stage after each productive batch
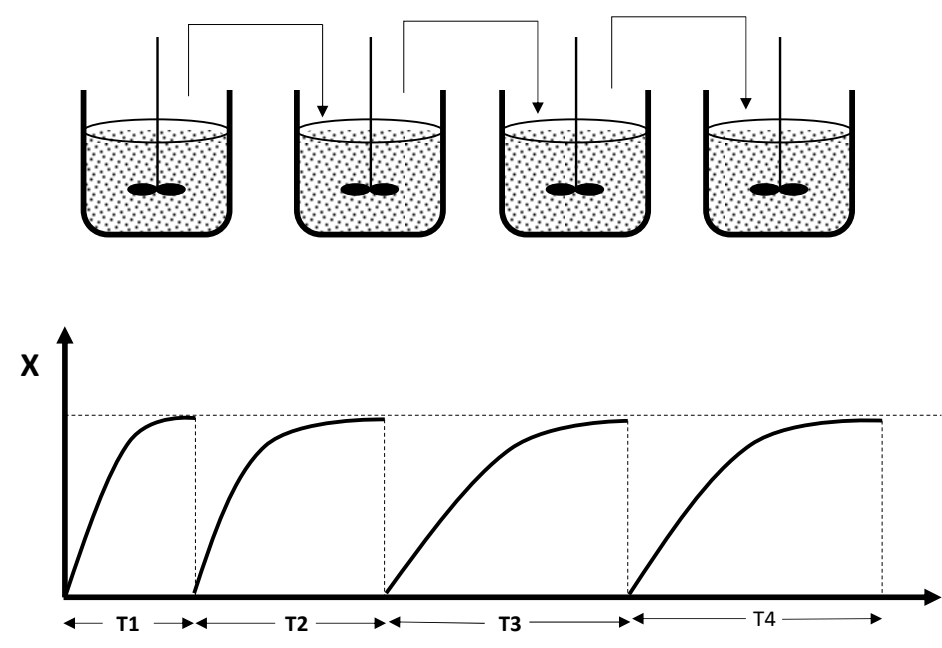

Time

Figure 1. Sequential batch reactors.

The model for the batch reactor was as follows:

$$
\int_{0}^{x} \frac{d X}{v(e, X)}=\int_{0}^{t} \frac{d t}{S_{i}}
$$

The Michaelis-Menten kinetics depend on the degree of conversion $(X)$ :

$$
v=\frac{k S_{i}(1-X)}{K+S_{i}(1-X)}
$$

The first-order inactivation kinetics were as follows:

$$
e=e_{0} \exp \left(k_{d} t\right)
$$

Then, by taking Equations (3) and (2) in Equation (1), separating the variables and integrating them, the following equation was obtained:

$$
\frac{S_{i}}{K} X-\ln (1-X)=\frac{K_{e_{0}}}{K k_{d}}\left(1-\exp \left(k_{d} t\right)\right)
$$

Equation (4) corresponds to the reactor behavior model in each productive batch, which was solved for $X$ using the "optimize solve" function of the SciPy Library with Python 3 software (3.7). Each batch was operated at a limit conversion of 0.9 . The next lot operated with the residual activity of the previous batch, until the residual activity was equal to $25 \%$ of initial activity. 
The reactivation step was performed under non-reactive conditions with kinetics described by Romero et al. [20], according to:

$$
\frac{e}{e_{0}}=(\gamma-\beta) \exp \left(-k_{r} t\right)+\beta
$$

The application of this reactivation model required an assumed value of $\beta$, which determined the level of reactivation reached. In this work, it was assumed that $\beta$ varied with each batch by 0.1 units, starting from the first phase of activation with a value of 0.95 , the second 0.85 , and continuing this way until sufficient lots were carried out to the activity limit $\left(0.25 \cdot e_{0}\right)$. The reactivation time was determined by assuming a limit of reactivation activity $e=e_{0} \cdot 0.95 \cdot \beta$. This activity limit reached by the reactivated enzyme corresponded to the initial activity of the next batch.

For the simulation without considering reactivation, the total time of each operation was calculated by:

$$
t=\sum_{j=1}^{n} t_{j}
$$

where $n$ is the number of batches.

For the simulation considering reactivation, the total operating time was calculated by:

$$
t=\sum_{j=1}^{n} t_{j}+\sum_{i=1}^{l} t_{i}
$$

where $l$ is the reactivation stage number.

The global specific productivity for the process with and without reactivation was determined by:

$$
P=\frac{\sum_{j=1}^{n} \frac{S_{i^{*} V_{j} X_{j}}}{m_{\text {biocat }}}}{\sum_{j=1}^{n} t_{j}+\sum_{i=1}^{l} t_{i}}
$$

\subsection{Simulation Flow Diagram}

The simulation flow diagram is provided in Figure 2. The flow diagram of the operation without reactivation is shown in Figure 2A, while the operation with intermediate reactivation is detailed in Figure 2B.

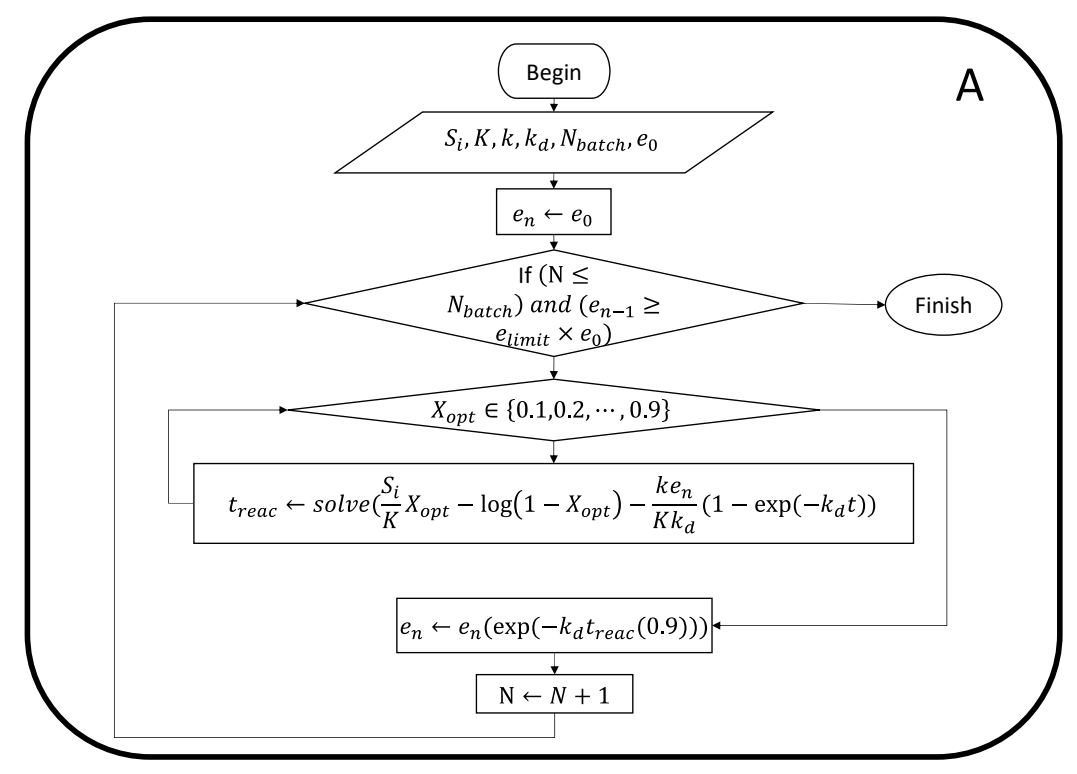

Figure 2. Cont. 


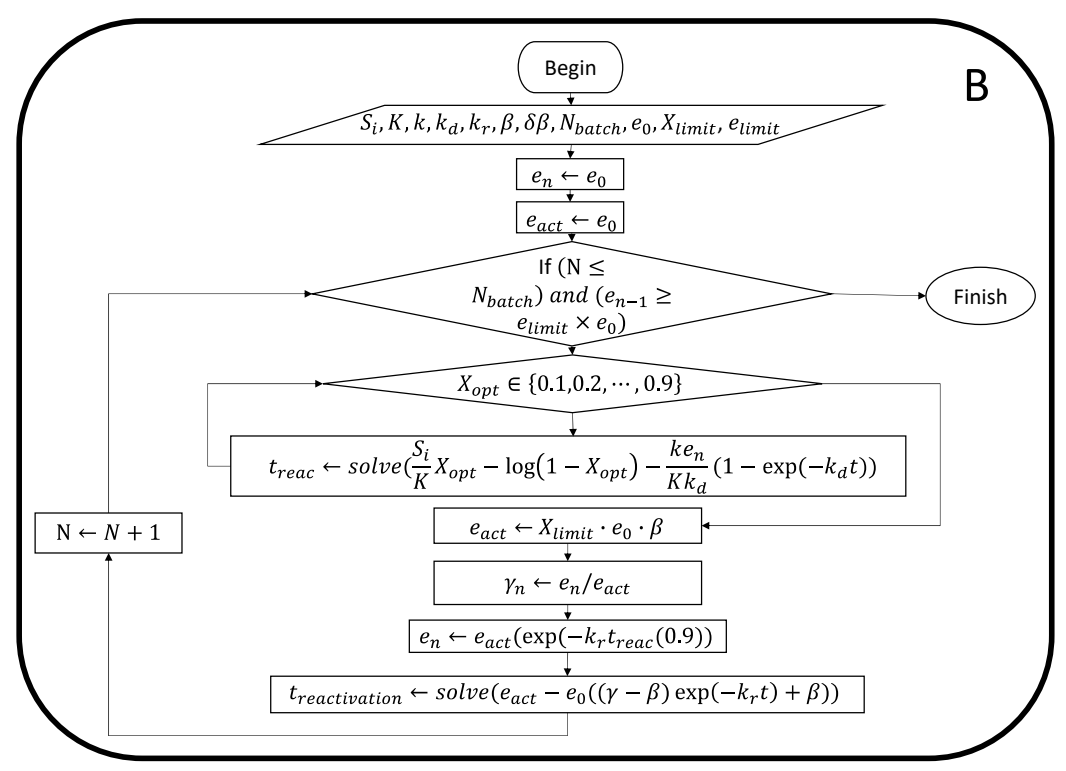

Figure 2. Simulation flow diagram: (A) without reactivation, (B) with reactivation.

Details regarding the program code can be found in the repository [29].

\section{Results and Discussion}

\subsection{Simulation with and without Reactivation}

As an example, here we report results of the evaluation of processes with and without reactivation, obtained through simulations using data from work reported in the field $[20,30,31]$. These works were chosen because there are few investigations in which kinetic parameters have been determined in the enzymatic reactivation processes. The parameters and starting data are summarized in Table 1.

Table 1. Data used to simulate system behavior.

\begin{tabular}{cc}
\hline Parameter & Value \\
\hline$S_{i}(\mathrm{mM})$ & 200 \\
$K(\mathrm{mM})$ & 10 \\
$k_{d}(1 / \mathrm{h})$ & 0.022 \\
$k_{r}(1 / \mathrm{h})$ & 0.1 \\
$k(1 / \mathrm{h})$ & 1 \\
$e_{0}(\mathrm{mmol} / \mathrm{g} \cdot \mathrm{h})$ & 18 \\
$m_{\text {biocat }}(\mathrm{g})$ & 1 \\
Reaction volume $(\mathrm{L})$ & 1 \\
\hline
\end{tabular}

Temperature is an important parameter, because each enzyme has its optimum reaction temperature [32], which can increase the productivity of the process. However, in the case of this work, an ambient temperature of $25^{\circ} \mathrm{C}$ was considered.

Figure 3 depicts the behavior of the conversion versus the time for the different batches without considering reactivation. It shows the gradual loss of enzymatic activity, as it takes more time to reach $90 \%$ conversion. In the case of Figure 3 , for $k_{d}=0.022\left(\mathrm{~h}^{-1}\right)$, the biocatalyst allows the operation of three batches, taking a total time of $66.8 \mathrm{~h}$. 


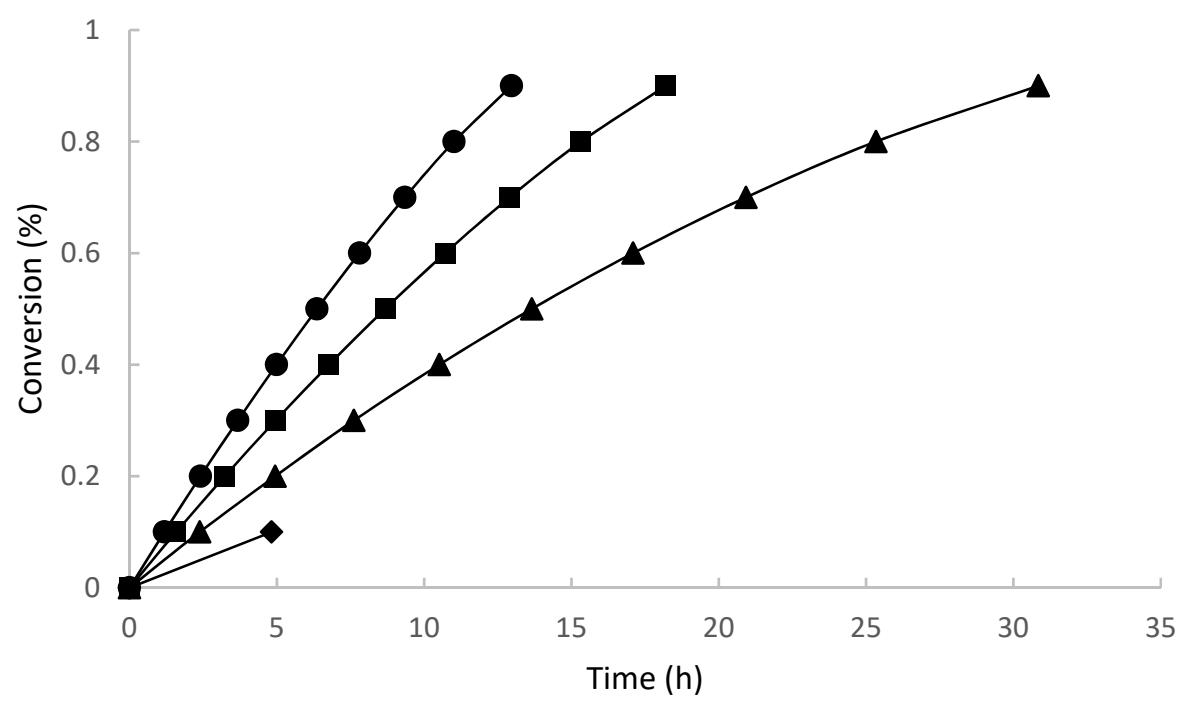

Figure 3. Operation of the enzymatic reactor by sequential batches with monophasic first-order

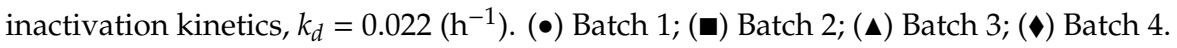

Figure 4 shows the change in the amount of product and the specific global productivity over time. The effect of inactivation can be seen in the curvature of the accumulation of product, which decreases over time. Meanwhile, instantaneous productivity throughout the operation shows a reduction between each operation batch, decreasing rapidly at the beginning of the operation and slowly later on, encompassing a total variation in specific productivity from 16.9 to $8 \mathrm{mM} / \mathrm{h} \cdot \mathrm{g}_{\text {biocat }}$.

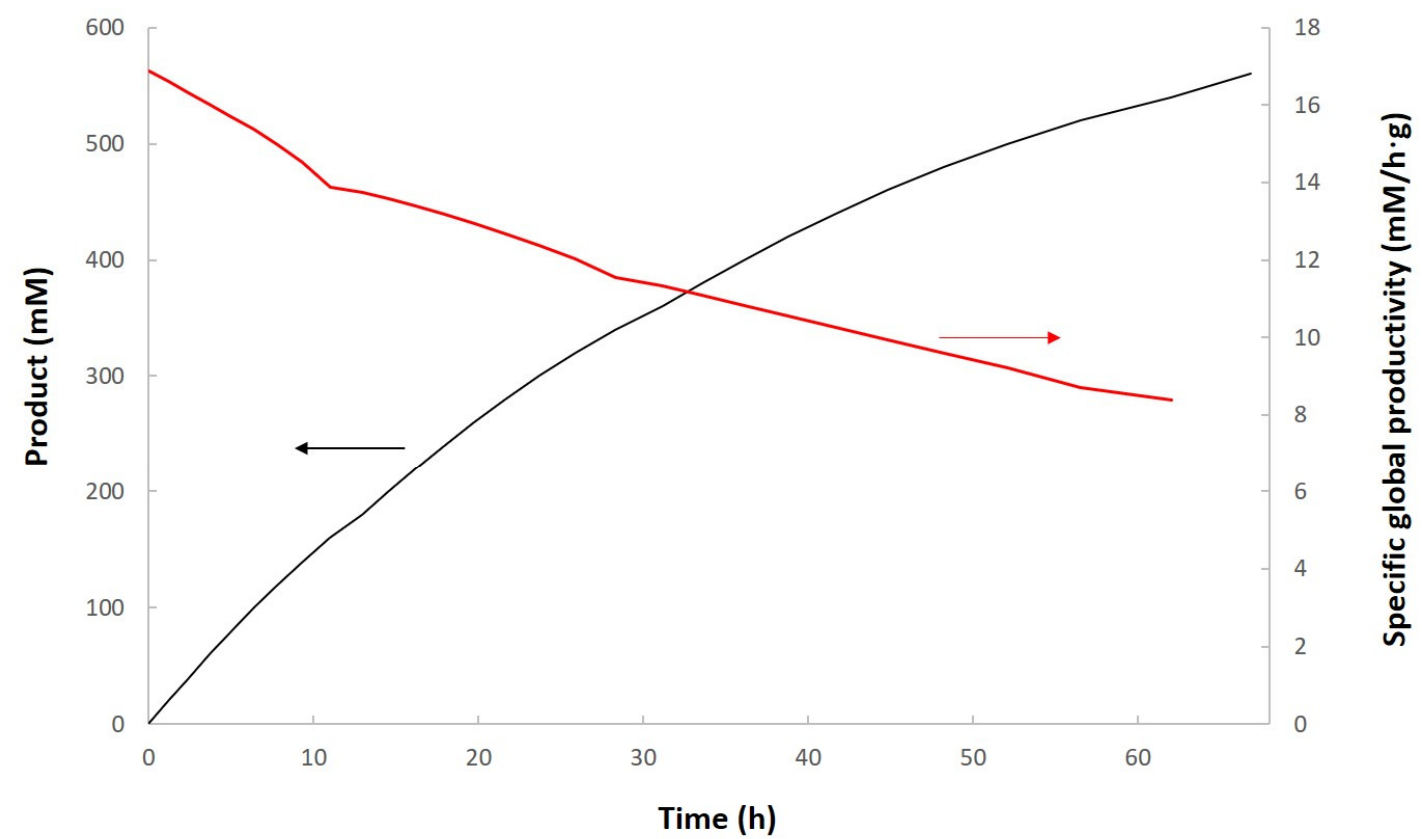

Figure 4. Product and specific global productivity over time during the operation of the successive batch enzyme reactor with monophasic first-order inactivation kinetics, $k_{d}=0.022 \mathrm{~h}$. Black line-Product $(\mathrm{mM})$; Red line-specific global productivity $\left(\mathrm{mM} / \mathrm{h} \cdot\right.$ g $\left._{\text {biocat }}\right)$.

When the conversion falls over each successive reaction batch, the decrease in the specific activity of the enzyme can also be seen (Figure 5). 


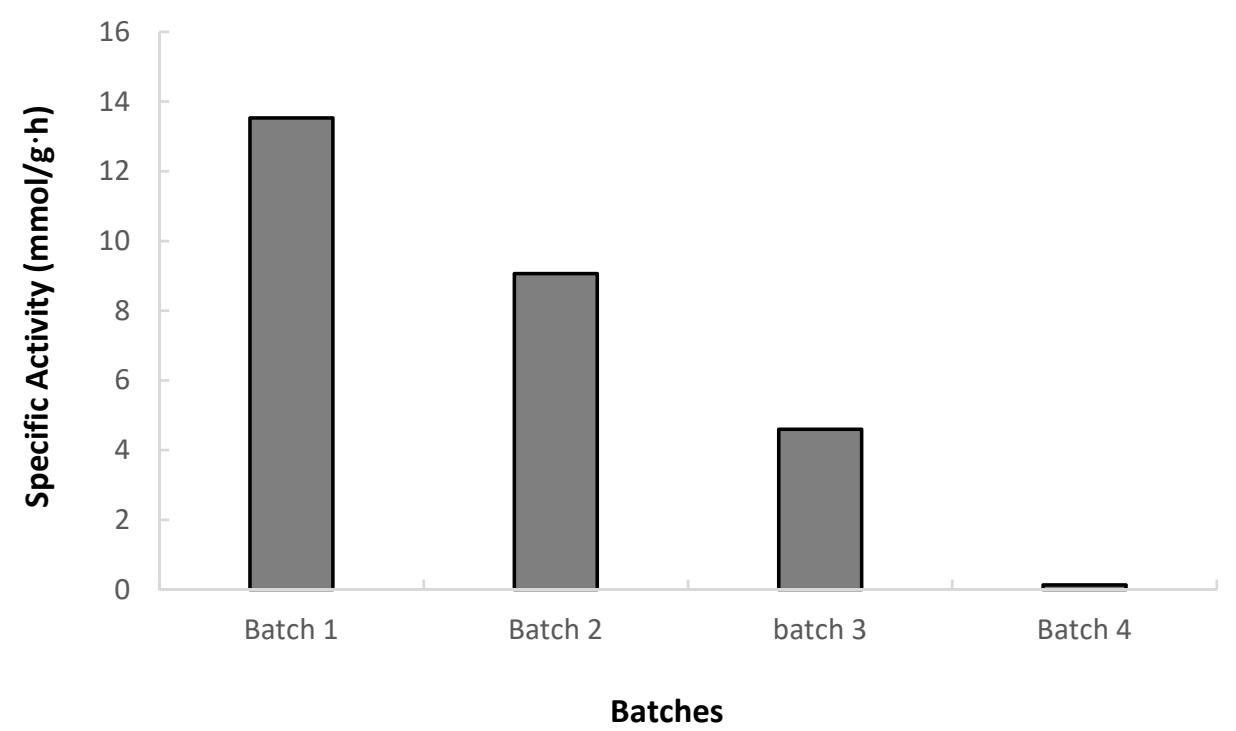

Figure 5. Specific activity during the operation of sequential enzymatic reactors with monophasic first-order inactivation kinetics, $k_{d}=0.02 \mathrm{~h}^{-1}$.

By incorporating interspersed enzymatic reactivation stages, it can be seen that the number of batches increases from four to six-and-a-half (Figure 6). Regarding the amount of product in Figure 7 , it can be seen that the accumulation of product increases with respect to the process without reactivation; however, in terms of productivity, it decreases with respect to the inactivation process from 8 to $4 \mathrm{mM} / \mathrm{h} \cdot \mathrm{g}_{\text {biocat }}$ due to the incorporation of the reactivation time.

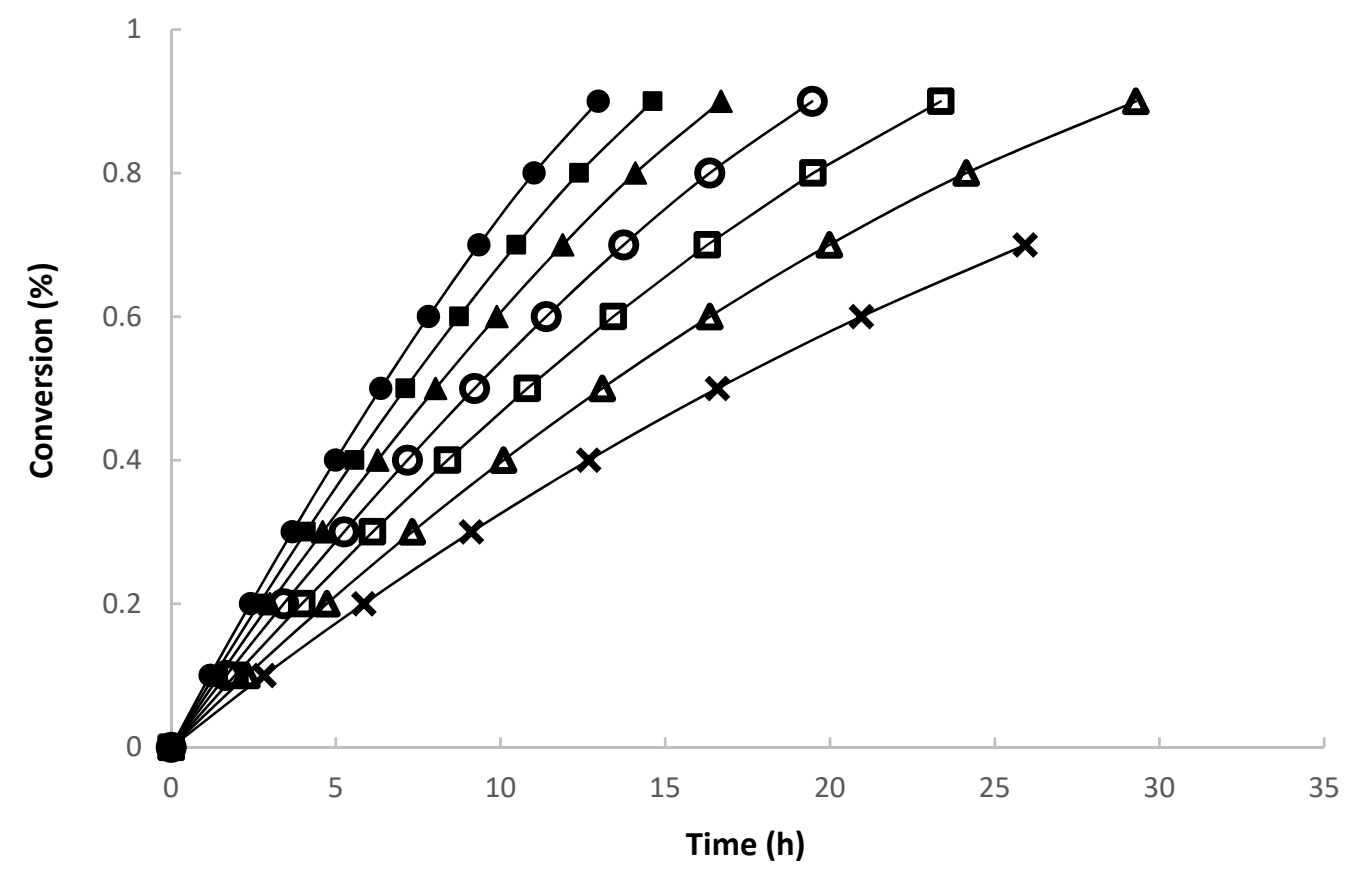

Figure 6. Operation of the enzymatic reactor by sequential batches with reactivation and monophasic

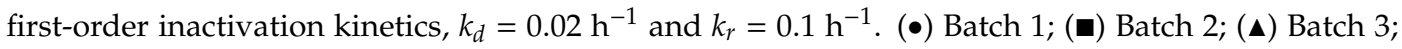
(○) Batch 4; () Batch 5; $(\Delta)$ Batch 6; $(\times)$ Batch 7. 


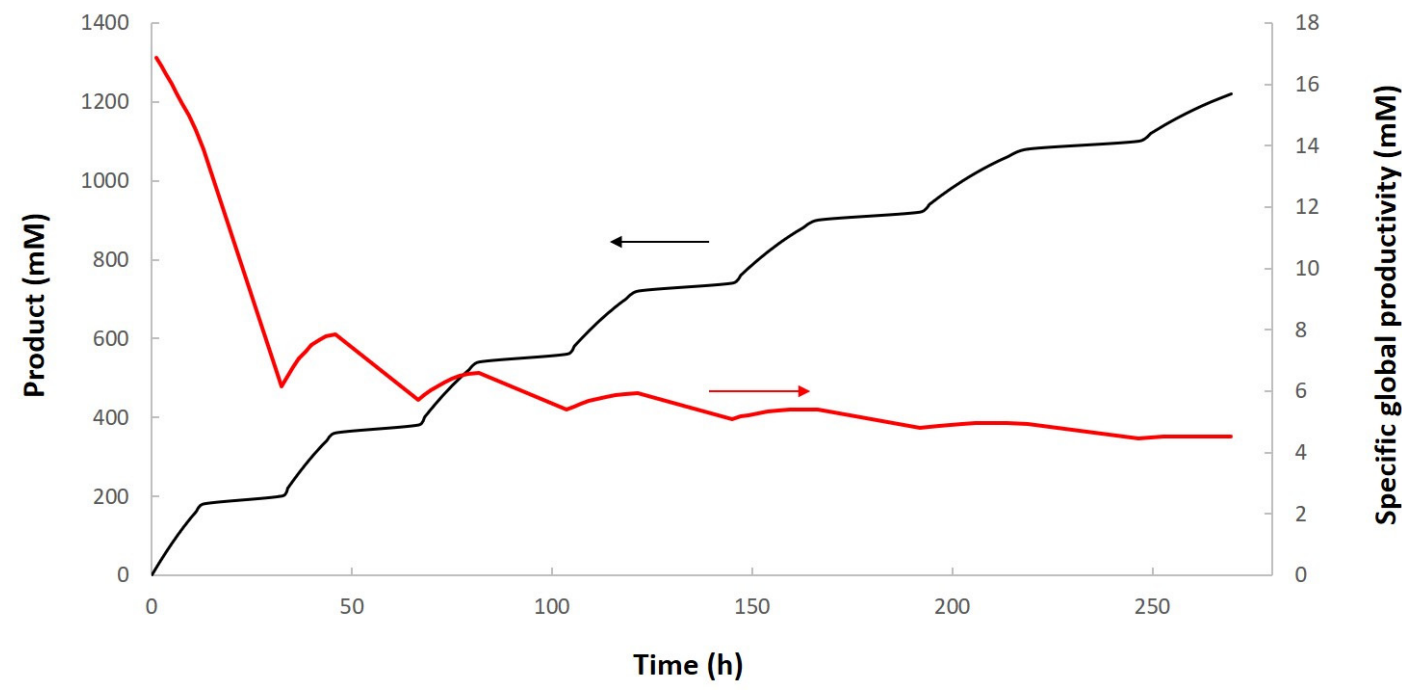

Figure 7. Product and specific global productivity over time, during the operation of the successive batch enzyme reactor with monophasic first-order inactivation kinetics, $k_{d}=0.022 \mathrm{~h}$ and reactivation $k_{r}=0.1 \mathrm{~h}^{-1}$. Black line-Product $(\mathrm{mM})$; Red line-Global specific productivity $\left(\mathrm{mM} / \mathrm{h} \cdot \mathrm{g}_{\text {biocat }}\right)$.

By increasing the number of batches, the life of the biocatalyst is also increased (Figure 8).

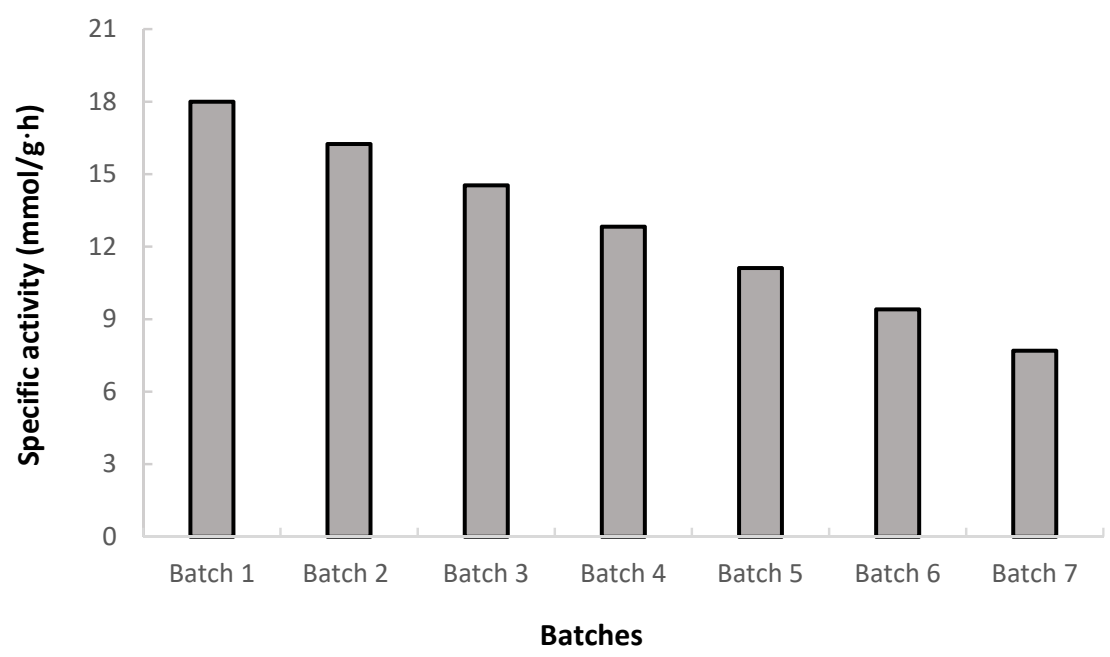

Figure 8. Specific activity during the operation of sequential enzymatic reactors with monophasic first-order inactivation kinetics, $k_{d}=0.02 \mathrm{~h}^{-1}$ and reactivation $k_{r}=0.1 \mathrm{~h}^{-1}$.

If considering a real operation, the reactivation would need to be economically justified. For example, if the enzyme is very expensive and the product has a high added value, after an economic analysis, perhaps the reactivation process should be used. On the contrary, if the biocatalyst is cheap and the final product is also cheap, it would not be advisable to reactivate it, since each reactivation stage costs money and time.

\subsection{Evaluation of Specific Global Productivity with Different Parameters and Statistical Analysis}

To compare the case with reactivation versus the case without reactivation using different parameters, random values were generated, where the $k_{d}$ values had a uniform distribution of 0.021-1.307, which was an assumption based on the reference values; $\beta$ had a uniform distribution between 0.85 and 0.95 ; and $k_{r}$ had a uniform distribution between 0.1 and 0.37 . Values of the other parameters used were fixed. The other parameters were also randomized. 
For each combination of parameters, the case was generated without reactivation and with reactivation. The analysis was developed using the stats, ggplot2 and Rmisc libraries from the R software [29] and the specific global productivity was calculated as a function of $k_{d}$ and $k_{r}$. For the case without reactivation, the $k_{r}$ parameter was not used. The overall specific productivity (total product per total process time) increased as a function of $k_{d}$. For the value $k_{d}=0.03$, the maximum was obtained with two batches, and the quantity of product was $360 \mathrm{mM}$ (Figure 9A). We believe that this is the product of routine numerical approximation problems to solve the nonlinear equation. In the case of reactivation, specific global productivity increased with $k_{d}$ and $k_{r}$ (Figure 9B). The maximum specific global productivity with reactivation occurred with one batch.

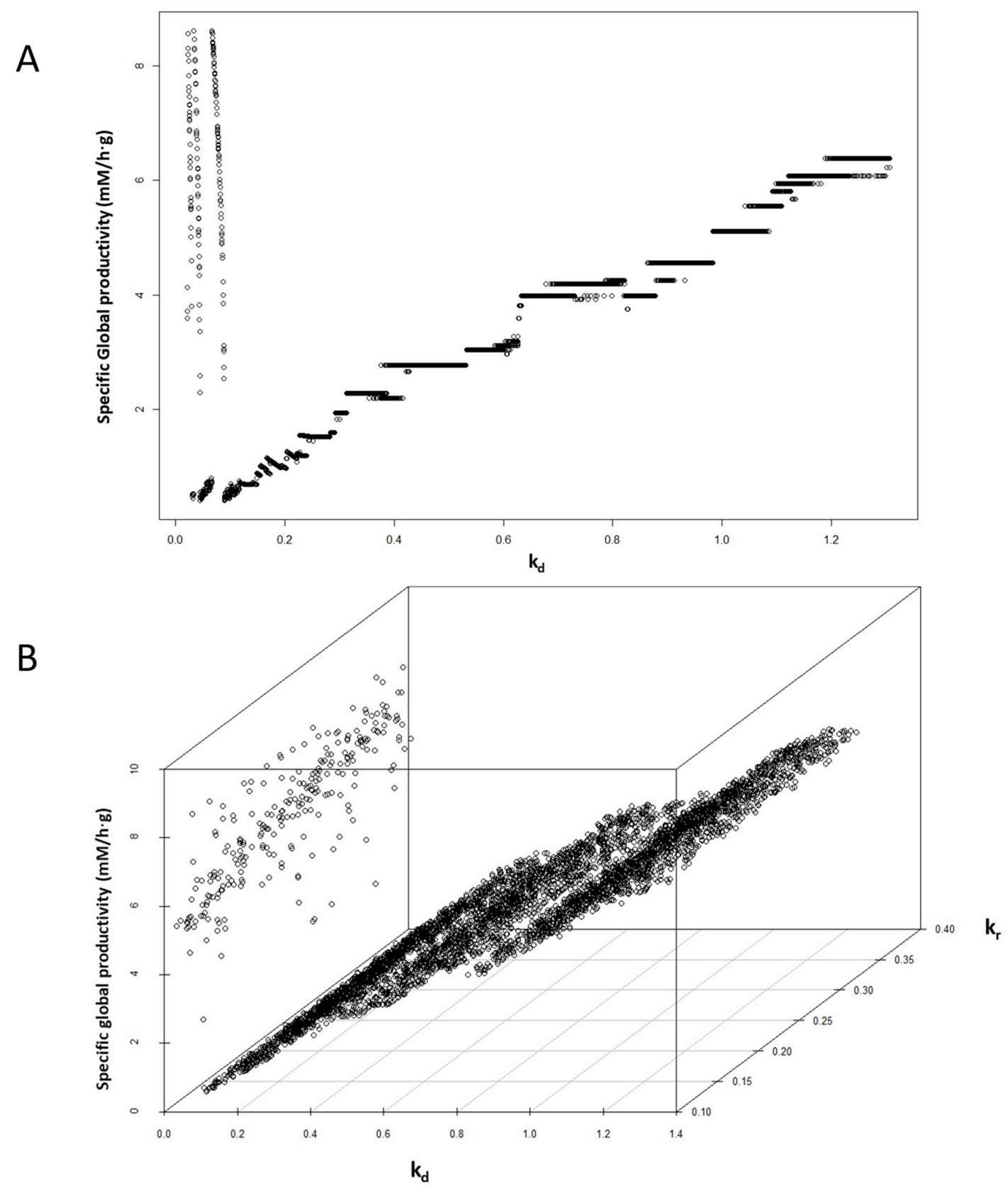

Figure 9. Specific global productivity under different conditions: (A) without inactivation and (B) with reactivation. 
It is important to note that maximum productivity does not mean more product; it means that the product was obtained in the shortest production time.

The average value of specific global productivity with reactivation was $3.79 \mathrm{mM} / \mathrm{h} \cdot \mathrm{g}$, while without reactivation it was $3.68 \mathrm{mM} / \mathrm{h} \cdot \mathrm{g}$. An ANOVA test revealed this difference to be significant $(p=0.002)$.

To study the differences between the case without reactivation and with reactivation, we used a MANOVA test, as data were normally distributed (Shapiro test, $p<0.001$ ). For each productivity, the difference between the media used was significant $\left(p=2.2 \times 10^{-16}\right)$, except for the first batch, which was not reactivation.

Figure 10 shows that the specific productivity per batch with reactivation was always higher than productivity without batch reactivation.

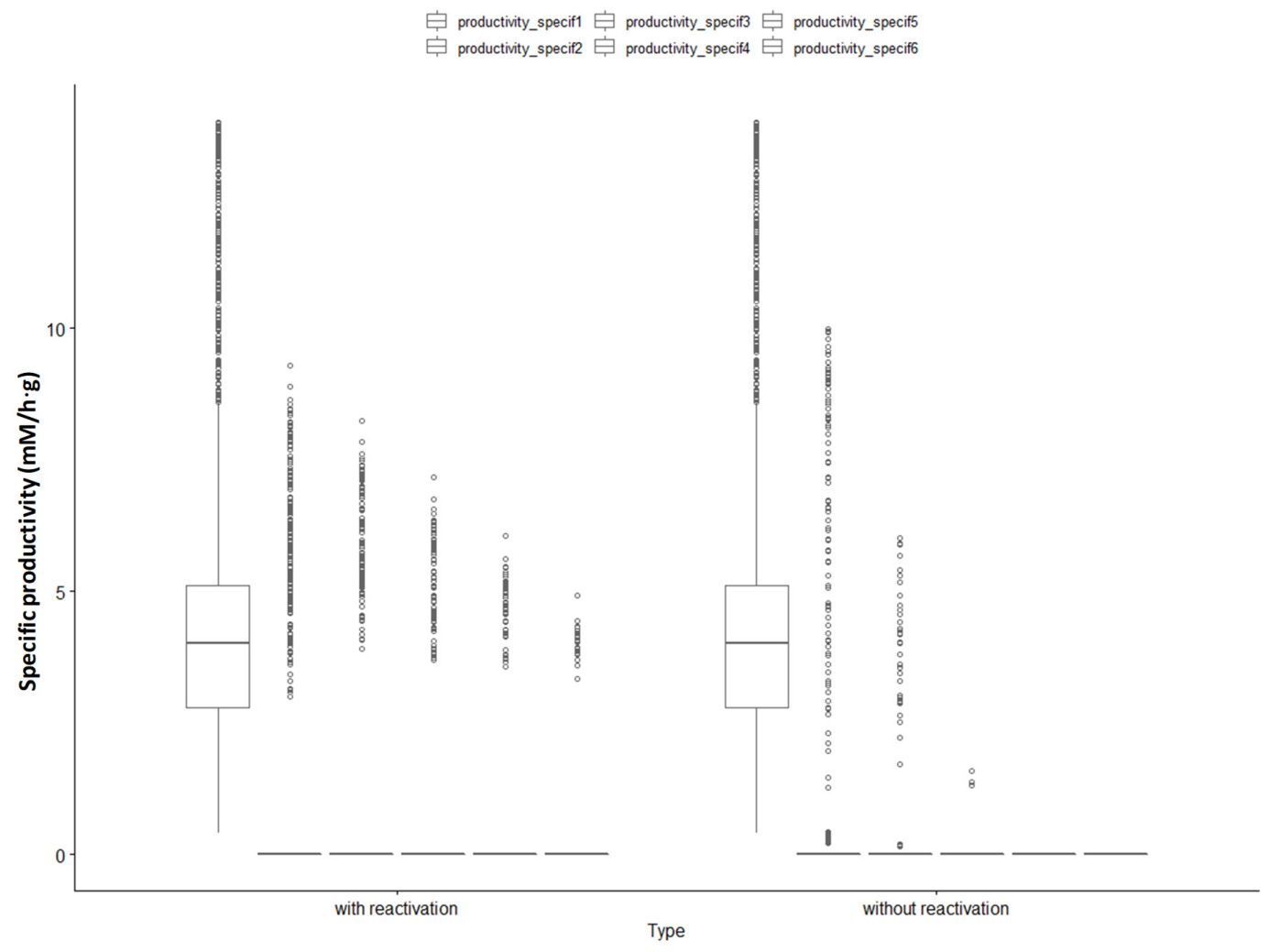

Figure 10. Specific productivity per batch with and without inactivation.

\section{Conclusions}

In summary, reactivation favors relevant productive parameters of the process, such as product accumulation and the useful life of the biocatalyst. In terms of global specific productivity, the operation with reactivation is slightly superior to the process without reactivation. ANOVA and MANOVA tests carried out at different values of $k_{d}$ and $k_{r}$ exhibited significant differences in favor of the process with reactivation, in the global productivity and that of each specific batch. In this sense, the reactivation operation has technical potential for those bioprocesses in which it is required to use a high-cost biocatalyst. This simulation also encourages the development of methods in the future to compare investment and operating costs, based on detailed experimental studies for a given process.

Author Contributions: Conceptualization, N.G. and F.A.C.; methodology, N.G., R.A.S. and F.A.C.; software, F.A.C. and R.A.S.; validation, N.G., F.A.C. and R.A.S.; formal analysis, N.G. and F.A.C.; investigation, N.G., F.A.C.; and R.A.S.; resources, N.G., F.A.C. and R.A.S.; data curation, N.G., F.A.C. and R.A.S.; writing-original draft preparation, N.G.; writing-review and editing, F.A.C.; visualization, F.A.C.; supervision, N.G.; funding acquisition, N.G. All authors have read and agreed to the published version of the manuscript.

Funding: This research was funded by FONDECYT, ANID, grant number 1200558.

Conflicts of Interest: The authors declare no conflict of interest. 


\section{Abbreviations}

$\begin{array}{ll}S_{i} & \text { Initial substrate concentration }(\mathrm{mM}) \\ X & \text { Conversion } \\ e & \text { Specific activity at time } \mathrm{t}(\mathrm{mM} / \mathrm{g} \cdot \mathrm{h}) \\ e_{0} & \text { Specific activity at time } 0(\mathrm{mM} / \mathrm{g} \cdot \mathrm{h}) \\ v & \text { Reaction rate }(\mathrm{mM} / \mathrm{h}) \\ K & \text { Affinity constant }(\mathrm{mM}) \\ k & \text { Catalytic constant }(1 / \mathrm{h}) \\ k_{d} & \text { Inactivation constant }(1 / \mathrm{h}) \\ t & \text { Time }(\mathrm{h}) \\ m_{\text {biocat }} & \text { Biocatalyst mass }(\mathrm{g}) \\ \gamma & \text { Relationship between the specific activities of the reactivated species and } \mathrm{e}_{0} \\ \beta & \text { Relationship between species-specific activities inactivated at the end of the batch } \\ k_{r} & \text { and } \mathrm{e}_{0} \\ \mathrm{~V} & \text { Reactivation constant }(1 / \mathrm{h})\end{array}$

\section{References}

1. Timson, D.J. Four challenges for better biocatalysts. Fermentation 2019, 5, 39. [CrossRef]

2. Chapman, J.; Ismail, A.E.; Dinu, C.Z. Industrial applications of enzymes: Recent advances, techniques, and outlooks. Catalysis 2018, 8, 238. [CrossRef]

3. Global Markets for Enzymes in Industrial Applications. Available online: https://www.bccresearch.com/ market-research/biotechnology/enzymes-industrial-applications-bio030h.html (accessed on 6 August 2020).

4. Sulman, E.M.; Matveeva, V.G.; Bronstein, L.M. Design of biocatalyst for efficient catalytic processes. Curr. Opin. Chem. Eng. 2019, 26, 1-8. [CrossRef]

5. Wu, M.-H.; Lin, M.-C.; Lee, C.-C.; Yu, S.-M.; Wang, A.H.-J.; David Ho, T.-H. Enhancement of laccase activity by pre-incubation with organic solvents. Sci. Rep. 2019, 9. [CrossRef] [PubMed]

6. Mohtashami, M.; Fooladi, J.; Haddad-Mashadrizeh, A.; Housaindokht, M.R.; Monhemi, H. Molecular mechanism of enzyme tolerance against organic solvents: Insights from molecular dynamics simulation. Int. J. Biol. Macromol. 2019, 122, 914-923. [CrossRef]

7. Janati-Fard, F.; Housaindokht, M.R.; Monemi, H.; Esmaeili, A.A.; Nakhaei Pour, A. The influence of two imidazolium-based ionic liquids on the structure and activity of glucose oxidase: Experimental and theoretical studies. Int. J. Biol. Macromol. 2018, 114, 656-665. [CrossRef]

8. Soler, G.; Bastida, A.; Blanco, R.M.; Fernández-Lafuente, R.; Guisán, J.M. Reactivation strategies by unfolding/refolding of chymotrypsin derivatives after inactivation by organic solvents. Biochim. Biophys. Acta 1997, 1339, 167-175. [CrossRef]

9. Henley, J.P.; Sadana, A. Deactivation theory. Biotechnol. Bioeng. 1986, 28, 1277-1285. [CrossRef]

10. Veille, C.; Zeikus, G.J. Hyperthermophilic enzymes: Sources, uses, and molecular mechanisms for thermostability. Microbiol. Mol. Biol. Rev. 2001, 65, 1-43. [CrossRef] [PubMed]

11. Zaks, A.; Klibanov, A.M. Enzymatic catalysis in organic media at $100{ }^{\circ}$ C. Science 1984, 224, $1249-1251$. [CrossRef] [PubMed]

12. Klibanov, A. Why are enzymes less active in organic solvents than in water? Trends Biotechnol. 1997, 15, 97-101. [CrossRef]

13. Klibanov, A.; Mozhaev, V.V. On the mechanism of irreversible thermoinactivation of enzymes and possibilities for reactivation of "irreversibly" inactivated enzymes. Biochem. Biophys. Res. Commun. 1978, 83, 1012-1017. [CrossRef]

14. Rios, N.S.; Mendez-Sanchez, C.; Arana-Peña, S.; Rueda, N.; Ortiz, C.; Goçalves, L.R.B.; Fernandez-Lafuente, R. Immobilization of lipase from Pseudomonas fluorescens on glyoxyl-octyl-agarose beads: Improved stability and reusability. Biochim. Biophys. Acta Proteins Proteom. 2019, 1867, 741-747. [CrossRef]

15. Stepankova, V.; Bidmanova, S.; Koudelakova, T.; Prokop, Z.; Chaloupkova, R.; Damborsky, J. Strategies for stabilization of enzymes in organic solvents. ACS Catal. 2013, 3, 2823-2836. [CrossRef]

16. Cao, L. Carrier-Bound Immobilized Enzymes: Principles, Applications and Design, 1st ed.; Wiley-VCH: Weinheim, Germany, 2005; pp. 169-293. 
17. Rodrigues, R.C.; Virgen-Ortíz, J.J.; dos Santos, J.C.S.; Berenguer-Murcia, Á.; Alcántara, A.R.; Barbosa, O.; Ortiz, C.; Fernandez-Lafuente, R. Immobilization of lipases on hydrophobic supports: Immobilization mechanism, advantages, problems, and solutions. Biotechnol. Adv 2019, 37, 746-770. [CrossRef]

18. Illanes, A. Enzyme Biocatalysis: Principles and Applications; Springer: Dordrecht, The Netherlands, 2008.

19. Mozhaev, V.V.; Berezin, I.V.; Martinek, K. Reactivation of immobilized enzymes. Application of immobilized enzymes/cells. Methods Enzymol. 1987, 135, 586-596. [PubMed]

20. Romero, O.; Vergara, J.; Fernández-Lafuente, R.; Guisán, J.M.; Illanes, A.; Wilson, L. Simple strategy of reactivation of a partially inactivated penicillin g-acylase biocatalyst in organic solvent and its impact on the synthesis of $\beta$-lactam antibiotics. Biotechnol. Bioeng. 2009, 103, 472-479. [CrossRef] [PubMed]

21. Rueda, N.; dos Santos, J.C.S.; Torres, R.; Barbosa, O.; Ortiz, C.; Fernández-Lafuente, R. Reactivation of lipases by the unfolding and refolding of covalently immobilized biocatalysts. RSC Adv. 2015, 5, 55588-55594. [CrossRef]

22. Bolivar, J.M.; Rocha-Martín, J.; Godoy, C.; Rodrigues, R.C.; Guisan, J.M. Complete reactivation of immobilized derivatives of a trimeric glutamate dehydrogenase from Thermus thermophilus. Process Biochem. 2010, 45, 107-113. [CrossRef]

23. Rodrigues, R.C.; Bolivar, J.M.; Palau-Orsa, A.; Volpato, G.; Ayubb, M.A.Z.; Fernandez-Lafuente, R.; Guisan, J.M. Positive effects of the multipoint covalent immobilization in the reactivation of partially inactivated derivatives of lipase from Thermomyces lanuginosus. Enzyme Microb. Technol. 2009, 44, 386-393. [CrossRef]

24. Mateo, C.; Abian, O.; Bernedo, M.; Cuenca, E.; Fuentes, M.; Fernández-Lorente, G.; Palomo, J.M.; Grazú, V.; Pessela, B.B.C.; Giacomini, C.; et al. Some special features of glyoxyl supports to immobilize proteins. Enzyme Microb. Technol. 2005, 37, 456-462. [CrossRef]

25. Romero, O.; Araya, E.; Illanes, A.; Wilson, L. Evaluation of kinetic parameters of immobilized penicillin G acylase subject to an inactivation and reactivation process. J. Mol. Catal. B Enzym. 2014, 104, 70-74. [CrossRef]

26. Wilson, L.; Illanes, A.; Romero, O. Effect of inactivation and reactivation conditions on activity recovery of enzyme catalysts. Electron. J. Biotechnol. 2013, 16. [CrossRef]

27. Guajardo, N.; Ahumada, K.; Domínguez de María, P.; Schrebler, R.A. Remarkable stability of Candida antarctica lipase B immobilized via cross-linking aggregates (CLEA) in deep eutectic solvents. Biocatal. Biotransform. 2019, 37, 106-114. [CrossRef]

28. Guajardo, N.; Domínguez de María, P.; Ahumada, K.; Schrebler, R.A.; Ramírez-Tagle, R.; Crespo, F.A.; Carlesi, C. Water as cosolvent: Nonviscous deep eutectic solvents for efficient lipase-catalyzed esterifications. ChemCatChem 2017, 9, 1393-1396. [CrossRef]

29. Simulation-Reactivation-Biocatalyst-Sequential-Batch-Reactors. Available online: https://github.com/ facrespo/Simulation-Reactivation-Biocatalyst-Sequential-Batch-Reactors (accessed on 5 November 2020).

30. Gabrovska, K.; Marinov, I.; Godjevargova, T.; Portaccio, M.; Lepore, M.; Granoc, V.; Diano, N.; Mita, D.G. The influence of the support nature on the kinetics parameters, inhibition constants and reactivation of immobilized acetylcholinesterase. Int. J. Biol. Macromol. 2008, 43, 339-345. [CrossRef]

31. Ladero, M.; Ferrero, R.; Vian, A.; Santos, A.; Garcia-Ochoa, F. Kinetic modelling of the thermal and pH inactivation of a thermostable $\beta$-galactosidase from Thermus sp. strain T2. Enzyme Microb. Technol. 2005, 37, 505-513. [CrossRef]

32. Grubecki, I.; Wojcik, M. How much of enzyme can be saved in the process with the optimal temperature control? J. Food Eng. 2013, 255-259. [CrossRef]

Publisher's Note: MDPI stays neutral with regard to jurisdictional claims in published maps and institutional affiliations.

(C) 2020 by the authors. Licensee MDPI, Basel, Switzerland. This article is an open access article distributed under the terms and conditions of the Creative Commons Attribution (CC BY) license (http://creativecommons.org/licenses/by/4.0/). 